\title{
CAN BEXAROTENE BE A CANDIDATE DRUG FOR THE MEDICAL THERAPY OF CUSHING SYNDROME?
}

\author{
Hulusi Atmaca ${ }^{1}$, Gülşen Işıklı ${ }^{2}$ Nilgün Sentürk ${ }^{3}$, Piltan Büyükkaya ${ }^{4}$ \\ Department of Endocrinology and Metabolism ${ }^{1}$, Internal Medicine ${ }^{2}$, Dermatology ${ }^{3}$ and \\ Hematology ${ }^{4}$, Ondokuz Mayis University Medical School, Samsun, Turkey
}

\section{INTRODUCTION}

We recently reported a patient with mycosis fungoides treated by bexarotene (Targretin $\left.{ }^{\circledR}\right)$, a synthetic retinoid analog with specific affinity for retinoid $\mathrm{X}$ receptor (1). The treatment induced hypertriglyceridemia and hypopituitarism characterized by hypogonadism, hypothyroidism and hypoadrenalism which has not been reported before that case. Here we report a second case with the some features. In this regard we suggested that bexarotene should be evaluated as a potential therapy for Cushing's syndrome.

\section{CASE}

A 59 year-old male patient was diagnosed as anaplastic lymphoma by right axillary lymph node biopsy and regarded as stage 3 in 2007. He was treated with 6 cycles of CHOP chemotherapy using cyclophosphamide, hydroxy doxorubicin, vincristine and prednisone. Thereafter he was treated with interferon alfa $2 b$ ( 3 times weekly) for one year. In 2010, because of skin involvement oral bexarotene $2 \times 75 \mathrm{mg}$ was initiated. Initially thyroid function tests ( TSH 0.49; normal range 0.27-4.2 $\mu \mathrm{IU} / \mathrm{ml}$, Free T4 1.1; normal range 0.93-1.7 ng/dl, Free T3 3.4; normal range 2-4.4 pg/ml) were normal and triglyceride level was $160 \mathrm{mg} / \mathrm{dl}$. At fourth month of bexarotene therapy triglyceride level increased up to $310 \mathrm{mg} / \mathrm{dl}$ and thyroid function tests were consistent with central hypothyroidism (TSH $0.025 \mu$ IU /ml, T4 0.55 $\mathrm{ng} / \mathrm{dl}$, T3 $1.8 \mathrm{pg} / \mathrm{ml}$ ). Fenofibrate and L-thyroxine $50 \mu_{\mathrm{g}}$ per day were started. However, he didn't use any medications including bexarotene and remained unfollowed for 2 years. In 2012, the patient was hospitalized for the progression of lymphoma. 18F-fluorodeoxyglucose positron emission tomography ( FDG PET) and abdominal computed tomography (CT) scans showed increased 18F-FDG uptake and multiple lymphadenopathies in mediastinum respectively. Adrenal glands were normal. Since thyroid function tests and triglyceride levels were in normal limits oral bexarotene was started and two months later fatigue and weakness were occurred. Morning fasting basal hormonal levels revealed central hypothyroidism, hypogonadism and hypoadrenalism (Table 1). Although insulin-like growth factor 1 (IGF-1) 
was lower than the normal range we did not carry out growth hormone (GH) stimulation tests to establish GH status. Pituitary magnetic resonance imaging (MRI) was normal. He was started prednisolone $7.5 \mathrm{mg}$ and L-thyroxine $50 \mu_{\mathrm{g}}$ per day and testosterone $100 \mathrm{mg}$ every three weeks intramuscularly. He felt well following hormone replacement therapy (HRT). Two weeks later following discharging he ceased his medicines including bexarotene. One week later he died from sepsis. During that period his random cortisol level was $33 \mu_{\mathrm{g} / \mathrm{dl}}$.

\section{DISCUSSION}

Bexarotene is currently approved for treatment of cutaneous T-cell lymphoma and is also under investigation for other cancers, such as lung, breast, and thyroid cancer. The most common side effects of bexarotene include hypertriglyceridaemia and central hypothyroidism (2). However, we recently reported a case with reversible hypopituitarism characterized by hypogonadism, hypothyroidism and hypoadrenalism induced five months after the treatment of bexarotene in a patient with mycosis fungoides (1). This is the second case that showed central hypogonadism, hypothyroidism and hypoadrenalism induced by bexarotene. In neither case did the prolactin and GH secretions appear to have been markedly affected.

In this case pituitary functions are not known prior to the bexarotene therapy. However, developing symptoms suggested pituitary failure and hormonal investigation confirmed hypopituitarism. Pituitary MRI did not reveal any lesion. During the sepsis period, after cessation of bexarotene, cortisol level was high enough to exclude adrenal failure. Therefore, these data suggested reversible adrenal failure in association with bexarotene use.

\section{CONCLUSIONS}

Clinicians should have high index of suspicion for hypopituitarism, especially adrenal failure, in patients under bexarotene therapy. Patients cortisol levels should be monitored, especially in whom suggestive symptoms developed.

This side effect may be promising for the treatment of TSH-secreting pituitary tumours and Cushing's syndrome. In this regard we suggest that bexarotene should be evaluated as a potential therapy for Cushing's syndrome in which the available medical drugs have limited efficacy and potential side effects.

\section{References}


1. Atmaca H, Islek I, Sentürk N. Reversible pituitary insufficiency due to bexarotene therapy in a patient with mycosis fungoides. Pituitary. doi. 10.1007/s11102-013-0523-z

2. Farol LT, Hymes KB (2004) Bexarotene: a clinical review. Expert Rev Anticancer Ther. doi.org/10.1586/14737140.4.2.180

Table 1. Laboratory tests at presentation.

\begin{tabular}{llll}
\hline Parameters (Normal ranges) & Results & Parameters (Normal ranges) & Results \\
\hline $\mathrm{Na}(135-145 \mathrm{mEq} / \mathrm{L})$ & 137 & Cortisol $(5-25 \mu \mathrm{g} / \mathrm{dl})$ & 1.2 \\
$\mathrm{~K}(3.5-5.5 \mathrm{mEq} / \mathrm{L})$ & 4 & ACTH $^{*}(9-52 \mathrm{pg} / \mathrm{ml})$ & 9.9 \\
FBG $\left.^{*}(70-100) \mathrm{mg} / \mathrm{dl}\right)$ & 70 & FSH $^{*}(1.5-12.4 \mathrm{mU} / \mathrm{ml})$ & 9.2 \\
BUN* $^{*}(5-24 \mathrm{mg} / \mathrm{dl})$ & 48 & LH $^{*}(1.7-8.6 \mathrm{mU} / \mathrm{ml})$ & 3.2 \\
Creatinine $(0.4-1.4 \mathrm{mg} / \mathrm{dl})$ & 1.2 & Total testosterone $(2.8-8 \mathrm{ng} / \mathrm{ml})$ & 1.01 \\
Free T3 $(2-4.4 \mathrm{pg} / \mathrm{ml})$ & 1.25 & Free testosterone $(8.6-54.6 \mathrm{pg} / \mathrm{ml})$ & 0.54 \\
Free T4 $(0.93-1.7 \mathrm{ng} / \mathrm{dl})$ & 0.81 & IGF-1 $(87-238 \mathrm{ng} / \mathrm{ml})$ & 73 \\
TSH* $(0.27-4.2 \mu \mathrm{IU} / \mathrm{ml})$ & 0.3 & Prolactin $(4-15.2 \mathrm{ng} / \mathrm{ml})$ & 8 \\
\hline
\end{tabular}

*FBG, fastin blood glucose; BUN, blood urea nitrogen; TSH, Thyroid-stimulating hormone;

ACTH, adrenocorticotropic hormone; FSH, Follicle-stimulating hormone; LH, Luteinizing hormone; IGF-1, Insulin-like growth factor 1 